\title{
Contemporary Issues in Protein Requirements and Consumption for Resistance Trained Athletes
}

\author{
Jacob Wilson and Gabriel J. Wilson \\ California State University East Bay, Hayward, CA. Address correspondence to \\ jwilson@abcbodybuilding.com
}

Received March 24, 2006/Accepted April 18, 2006.

\section{ABSTRACT}

In recent years an explosion of research papers concerning protein consumption has been published. The need to consolidate this information has become critical from both practical and future research standpoints. For this reason, the following paper presents an in depth analysis of contemporary issues in protein requirements and consumption for resistance trained athletes. Specifically, the paper covers: 1.) protein requirements for resistance trained athletes; 2.) the effect of the digestion rate of protein on muscular protein balance; 3.) the optimal timing of protein intake relative to exercise; 4.) the optimal pattern of protein ingestion, relative to how an individual should consume their protein throughout a 24 hour period, and what sources are utilized during this time frame; 5.) protein composition and its interaction with measures of protein balance and strength performance; 6.) the combination of protein and carbohydrates on plasma insulin levels and protein balance; 7.) the efficacy of protein supplements and whole food protein sources. Our goal is to provide the reader with practical information in optimizing protein intake as well as for provision of sound advice to their clients. Finally, special care was taken to provide future research implications. Journal of the International Society of Sports Nutrition. 3(1):7-27, 2006

Key Words: sports supplements, protein, resistance training, protein timing

\section{INTRODUCTION}

In recent years an explosion of information concerning sports nutrition has surfaced. This research has sought to analyze the optimization of whole food diets, as well as the efficacy of adding various supplements to the non supplemented diet. Particular subjects which have generated great debate and interest have concerned both the proper consumption of whole food and supplemental forms of proteins. In this context, a number of topics, such as protein requirements have been reexamined through extensive experimentation. In particular numerous variables have been identified which make the determination of protein requirements for resistance trained athletes particularly difficult ${ }^{1}$. Variables which have been demonstrated to affect the efficacy of any given protein intake include the timing of protein ingestion ${ }^{1-4}$, the pattern of protein ingestion ${ }^{1}$, the rate of digestion ${ }^{5}$, the effect of added energy such as carbohydrates to a protein containing meal ${ }^{6}$, and the quality of protein intake ${ }^{7}$. The interaction of these variables is absolutely essential for professionals attempting to prescribe a diet that optimizes muscular protein balance and indexes of performance in resistance trained athletes. As a result the need to consolidate this information has become critical. Therefore, the purpose of this review article is to critically examine these contemporary issues in protein consumption and how they interact with protein requirements for resistance trained athletes.

Protein Requirements for Resistance Trained Athletes. In a recent Meta Analysis on protein requirements Rand et al. defined the protein requirement in healthy adults as "the continuing intake of dietary protein that is sufficient to achieve body nitrogen equilibrium (zero balance) in an initially healthy person of acceptable body composition at energy balance and under conditions of moderate physical activity..." An individual's protein needs are assumed to have been met when the amount of nitrogen consumed is equal to the amount of nitrogen excreted or lost (zero nitrogen balance) ${ }^{8-}$ ${ }^{10}$. In the occurrence that the amount of nitrogen consumed exceeds the amount of nitrogen lost then the individual is in a state of positive nitrogen balance, and is generally assumed to be in an 
anabolic state ${ }^{9}$. Conversely when the amount of nitrogen excreted exceeds the amount of nitrogen consumed, the individual has entered into negative nitrogen balance, and is assumed to be in a state of net bodily protein loss (catabolic state) ${ }^{9}$. Based on this definition, the Recommended Daily Allowance (RDA), meant to suffice for $97.5 \%$ of the population is 0.8 grams of protein per kilogram of bodyweight 8,9 . However, strength training athletes generally consume a great deal more than the RDA ${ }^{11-14}$, with the rationale that their protein requirements exceed that of the general population ${ }^{12}$. Therefore, a number of studies have examined athletes' protein requirements based on the nitrogen balance technique $13-15$.

It is important to note however, that a number of problems have been associated with utilization of the nitrogen balance technique in both athletic and non athletic populations ${ }^{1,12,13}$. As an illustration, Wolfe ${ }^{18}$ suggested that the rate of ventilation during exercise can become high enough to make measurements of nitrogen loss through exhalation impossible. Further, Tomé et al. ${ }^{19}$ posited that nitrogen losses through gas, excessive sweating, and overestimation of nitrogen intake can lead to false results. A further problem was identified by Wolfe et al. ${ }^{20}$ who found that light exercise increased the oxidation of the amino acid leucine without increasing urea production. One possible rationale involves utilizing the nitrogen obtained from leucine catabolism for the formation of non essential amino acids which are incorporated or recycled into other bodily or plasma proteins ${ }^{1,20-22}$. If this is the case, then protein needs for maintenance of muscle tissue may be underestimated.

It is also critical to recognize that a minimal protein requirement does not equate to an optimal protein intake. Indeed, strength athletes and bodybuilders are interested in stimulating muscular hypertrophy well beyond levels required for maintenance ${ }^{1}$. Further, evidence suggests that nitrogen balance may be able to occur at protein intakes which fall below those needed to optimize body composition and performance measures ${ }^{1,23}$.

While these problems are recognized, it is still important to analyze the evidence presented from nitrogen balance studies as "this method remains the primary approach for determining protein requirement in adults, in large part because there is no validated or accepted alternative ${ }^{8 \%}$. It is also important as a number of studies have increased the validity of their data through the use of tracer methods along with nitrogen balance techniques ${ }^{13}$. Tracer techniques consist of infusing an amino acid(s) with a radioactive carbon, hydrogen, or nitrogen atom into participants until the amount of tracer entering the body is balanced with the amount excreted (steady state) ${ }^{24}$. After this process has occurred, experimenters can determine the amount of whole body amino acid oxidation and degradation by measuring the amounts of radioactive carbon or nitrogen in the participant's breath or urine ${ }^{24}$.

Studies Relevant to the Determination of Protein Requirements for Strength Training Athletes. The following paragraphs will discuss relevant studies involved in determining protein requirements for strength training athletes and bodybuilders. In a classic study Tarnopolsky et al. ${ }^{15}$ investigated the effects of high vs. low protein intakes on bodybuilders with greater than three years of intense training experience. The bodybuilders underwent two experimental protocols consisting of high and low protein intakes. In the high protein experiment, bodybuilders consumed an average protein intake of 2.77 g.kg-1.day-1. Training consisted of a three day split in which participants rotated between upper, mid, and lower body workouts, with an average of 35 sets per body part, utilizing 8-12 repetitions, at approximately 75 minutes per training session. In the low protein condition bodybuilders were administered an isocaloric diet, with protein intake lowered to $1.05 \mathrm{~g} \cdot \mathrm{kg}^{-1} \cdot \mathrm{day}^{-1}$.

Nitrogen balance in the low protein condition resulted in two of the six bodybuilders entering into negative nitrogen balance. A linear regression calculation of protein requirements needed to attain zero nitrogen balance indicated that bodybuilders required $1.2 \mathrm{~g} \cdot \mathrm{kg}^{-1} \cdot \mathrm{day}^{-1}$ with a correction factor of 1 standard deviation (SD) unit added. When comparing low protein diets to high protein diets, it was found that nitrogen balance was significantly more positive for the high protein condition than the low protein condition (13.35 grams of $\mathrm{N}$ retained vs. 1.06 grams of $\mathrm{N}$ retained). Surprisingly, the authors did not find a significant change in lean body mass (LBM). The authors suggested that these results may have been due to overestimation of nitrogen retention. However, Tipton and Wolfe ${ }^{1}$ recently postulated that the protein deposition may have been too small to detect. This explanation appears valid considering the fact that these were experienced bodybuilders who were in 'maintenance' and that each condition in the study lasted for only a 10 day duration. 
In a similar manner Hegsted ${ }^{16}$ analyzed a number of studies in children, pregnant women, and adult men. $\mathrm{He}$ found that protein consumption caused an "apparent retention" of 20 percent of the nitrogen consumed above maintenance up to $0.5 \mathrm{~g} / \mathrm{kg}$ per day of nitrogen (3.1 grams of protein per $\mathrm{kg}$ ). However as with Tarnopolsky et al. ${ }^{15}$ he suggested that these results did not reflect proportional body composition changes, especially in non pregnant adults and may have been due to underestimations in nitrogen loss. As with the Tarnopolsky et al. ${ }^{15}$ experiments the majority of the studies analyzed by Hegsted ${ }^{16}$ only lasted on the order of days to weeks, which is generally too short to find a statistically significant change in LBM ${ }^{1}$. Further, nitrogen retention does not directly reflect changes in skeletal muscle mass due to much of the nitrogen being utilized for the formation of plasma proteins such as albumen ${ }^{1}$.

In a second study conducted by Tarnopolsky et al. ${ }^{13}$ strength athletes with 3-9 months of training experience and sedentary participants were analyzed in response to low $\left(0.8 \mathrm{~g} \mathrm{~kg}^{-1} \cdot \mathrm{day}^{-1}\right)$, moderate $(1.4$ $\left.\mathrm{g} \cdot \mathrm{kg}^{-1} \cdot \mathrm{day}^{-1}\right)$ and high protein intakes $\left(2.4 \mathrm{~g} \cdot \mathrm{kg}^{-1}\right.$.

day $\left.^{-1}\right)$. Utilizing linear regression, protein requirements for sedentary and strength athletes were found to be 0.69 and $1.4 \mathrm{~g} \cdot \mathrm{kg}^{-1} \cdot \mathrm{day}^{-1}$ respectively. In addition to nitrogen balance however, the authors utilized a tracer technique to measure whole body protein synthesis (WBPS). Results indicated that WBPS increased from low to moderate protein intake, with no significant increase from the moderate to high condition.

Further, the rate of leucine oxidation increased as protein intakes increased, indicating that a great deal of the excess protein intake was utilized as energy. One variable in this study that the authors mentioned was that the additional protein from the moderate to high protein conditions was added from whey, making the diet a higher quality of protein relative to the low and moderate protein diets. The authors suggested that this may have caused an underestimation of protein requirements. It is also important to note, that the rapid digestion rate of whey protein naturally increases oxidation rates of amino acids ${ }^{25,26}$, which may have over inflated the increase in leucine oxidation seen. The discrepancy in protein needs between the athletes in this study and the participants in the Tarnopolsky et al. ${ }^{15}$ study may have been due to training experience. It has been suggested that strength training athletes with greater experience become more efficient at protein utilization ${ }^{27}$. This contention was supported by Lemon et al. ${ }^{27}$ who found that novice bodybuilders in the early stages of training were in negative nitrogen balance (-3.4 grams of $\mathrm{N}$ ) when consuming $1.35 \mathrm{~g} \cdot \mathrm{kg}^{-1} \cdot \mathrm{day}^{-1}$ and in positive nitrogen balance $(+8.9 \mathrm{~g})$ when consuming 2.62 grams of protein daily. Utilizing regression analysis and adding a safety buffer of 2 SD units, the protein needs to acquire zero nitrogen balance was calculated to be

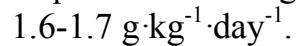

Studies based on body composition and performance variables. While the above investigations lasted on the order of weeks, a number of recent studies have utilized longer experimental protocols with more direct measures of performance. In this context Falvo and colleagues ${ }^{28}$ investigated the effect of a high protein diet $\left(2.00 \mathrm{~g} \cdot \mathrm{kg}^{-1} \cdot \mathrm{day}^{-1}\right)$ and a relatively lower protein diet $\left(1.24 \mathrm{~g} \cdot \mathrm{kg}^{-1} \cdot \mathrm{day}^{-1}\right)$ on bench press 1-RM and squat 1-RM performance during a 12 week resistance training program in experienced resistance trained participants. While there was no significant difference in 1-RM bench press performance, the high protein group improved their 1-RM squat $(23.6 \pm 13.6 \mathrm{~kg})$ to a greater extent than the low protein group $(9.09 \pm 11.86 \mathrm{~kg})$. In a similar study by Vukovich et al. ${ }^{29}$ divided 51 male and female participants into two groups. Group one received a 40 gram whey protein supplement twice daily, while group two received a carbohydrate placebo during a six month resistance training program. Participants in the supplemented group averaged twice the protein intake $(2.2 \mathrm{~g} / \mathrm{kg}$ body weight) as the placebo group ( $1.1 \mathrm{~g} / \mathrm{kg}$ body weight). The protein supplemented group experienced significantly greater strength gains than the placebo group in bench press and hip sled tasks (see Figure $1)$.

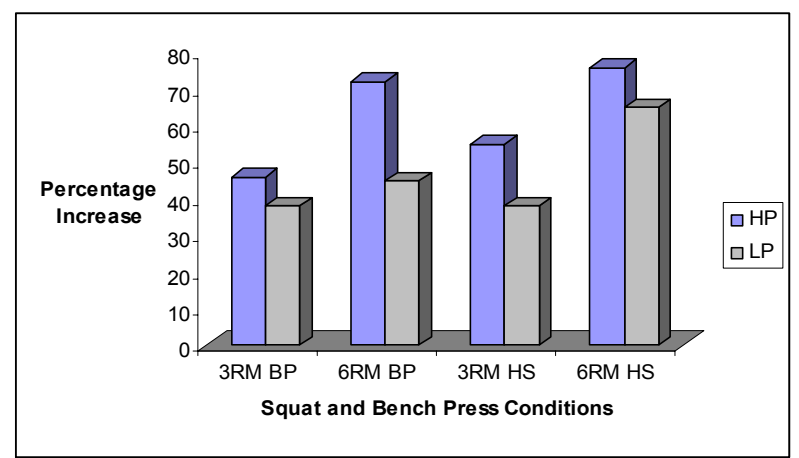

Figure 1. Percentage increase in Squat and Bench Press in High Protein (HP) and Low Protein (LP) conditions during six months of resistance training. Data from Vukovich et al. $^{29}$

Recently Burke et al. ${ }^{30}$ randomly assigned 36 individuals to a whey protein (WP) supplemented 
group, a whey protein and creatine supplemented group (WPC), or a placebo group. Whey protein was given at 1.2 grams per $\mathrm{kg}$ of bodyweight in addition to the participants' normal diet. It was found that lean tissue increased to the greatest extent in the WPC group compared to other groups, and that the WP group gained more lean muscle mass than the placebo. This same trend was found in indexes of strength as well.

The above studies indicate that protein requirements for athletes far exceed the daily recommended allowance. In fact, a number of reviews from respected authorities have surfaced on dietary protein requirements which have ranged form 1.2-2.2 grams of protein per $\mathrm{kg}$ of bodyweight (see Table-1) $1,7,14$, 23,24,31-33

Table 1 - Summary of recommendations from 8 review papers and book chapters on total grams of protein per kilogram of bodyweight per day for athletes.

\begin{tabular}{|l|c|}
\hline \multicolumn{1}{|c|}{ Author of Review } & $\begin{array}{c}\text { Recommended } \\
\text { Protein Requirements }\end{array}$ \\
\hline Batheja et al. ${ }^{33}$ & $1.2-2.2 \mathrm{~g}$ \\
\hline Kreider $^{32}$ & $1.3-1.8 \mathrm{~g}$ \\
\hline Lemon $^{14}$ & $1.2-1.7 \mathrm{~g}$ \\
\hline Lemon $^{23}$ & $1.6-1.8 \mathrm{~g}$ \\
\hline Lemon $^{24}$ & $1.5-2.0 \mathrm{~g}$ \\
\hline Wolf $^{18}$ & $\begin{array}{l}\text { May not be possible } \\
\text { given the number of } \\
\text { variables involved }\end{array}$ \\
\hline Tipton et al. & \\
\hline Phillips &
\end{tabular}

Further variables which affect protein requirements. It has been well established that energy intake has a substantial impact on nitrogen balance (readers are referred to the following excellent reviews: Milward ${ }^{34}$ and Munro ${ }^{35}$ ). In a recent review Milward summarized this issue by stating that "NB studies need to be conducted in individuals in energy balance, because if energy requirements are underestimated then protein requirements will be overestimated, and vice versa ${ }^{34}$." The rationale is that a decrease in energy intake causes an individual to increase the utilization of stored amino acids for fuel ${ }^{23}$. In this context Pellot et al. (as cited in Milward ${ }^{34}$ ) analyzed the effects of varying caloric intake from 2,100 to 4,200 calories in a number of studies examining daily protein requirements. They found that protein requirements for zero nitrogen balance at daily energy intakes of 30,45 , and $60 \mathrm{kcal} / \mathrm{kg}$ were $1.42,0.87$, and 0.32 $\mathrm{g} / \mathrm{kg} / \mathrm{d}$, respectively. According to their calculations a $90 \mathrm{~kg}$ man (approximately 200 pounds) with moderate physical activity, consuming $2700 \mathrm{kcal}$ per day $(30 \mathrm{kcal} / \mathrm{kg})$ would need 123 grams of protein daily to achieve zero nitrogen balance. Increasing these calories to $4000(45 \mathrm{kcal} / \mathrm{kg})$ would lower his needs to approximately 80 grams daily. Therefore, the combination of a decreased energy intake, with high levels of physical activity may increase the nitrogen needs of athletes to a greater extent.

An additional variable affecting protein requirements is the length of intense training. Of particular interest are lengths of training times which exceed the resistance training data collected by current studies on nitrogen balance and resistance training. In a number of the most frequently cited studies $13,15,27$ total training times do not typically exceed 75 minutes. This led McArdle et al. to state that "research has not pinpointed the actual protein requirements for individuals who train 4-6 hours daily using resistive type exercise ${ }^{12}$." It should also be noted that endurance superimposed on resistance training may further increase the protein requirements of resistance trained individuals ${ }^{27}$. As an illustration Consolazio ${ }^{36}$ had participants who utilized a combination of resistance and endurance training consume protein in $2.8 \mathrm{~g} \cdot \mathrm{kg}^{-1} \cdot \mathrm{day}^{-1}$ or 1.4 $\mathrm{g} \cdot \mathrm{kg}^{-1} \cdot \mathrm{day}^{-1}$ for 40 days. The experimenters found significantly greater nitrogen balance and lean body mass in the high protein group than the lower protein group, even though $1.4 \mathrm{~g} \cdot \mathrm{kg}^{-1} \cdot \mathrm{day}^{-1}$ was relatively high compared to the RDA. Lemon et al. ${ }^{27}$ posited that the study was confounded as endurance exercise increases the oxidation of proteins more than resistance training. Further, both resistance training and endurance exercise increase protein synthesis, leading Lemon et al. ${ }^{27}$ to conclude that their additive effects may enhance protein requirements relative to resistance training alone. As such, future research on protein requirements for athletes who superimpose resistance training with endurance exercise could provide essential data.

It is important to further analyze two critical points that Lemon et al. ${ }^{27}$ addressed. First the authors highlighted the importance of increased protein 
synthesis from exercise and second they suggested that the transient increases in protein synthesis seen in varying forms of exercise are additive. This led Lemon ${ }^{23}$ to discuss the importance of various interventions or supplements which can potentiate the normal anabolic response of an exercise session. For example, creatine may heighten the rate of protein synthesis following exercise ${ }^{23,37}$. The increase in protein synthesis may be due to increased myofibrillar hydration ${ }^{38,39}$, or a heightened stimulus triggered through an increased capacity to perform work $^{23}$.

It is also important to emphasize the additive effects of transient increases in protein synthesis. It has been suggested that once an individual consumes an adequate supply of amino acids to meet specific needs that further increases in protein synthesis will be balanced with lowered rates of protein synthesis during post absorptive periods ${ }^{40}$. However this is at odds with evidence which demonstrates that acute increases in skeletal muscular protein synthesis (MPS) are additive to normal MPS balance, and that there does not appear to be compensation at night ${ }^{40}$. In this context, increasing the frequency of training may enhance an individual's capacity to utilize amino acids for protein synthesis, which may provide part of the rationale for the enhanced lean body mass (LBM) seen in experienced weight lifters who have distributed training volume from one to two daily sessions ${ }^{41-43}$.

Recent Trends in Protein Requirements. A number of recent studies have found varying results from any given protein intake when factors such as the timing of protein ingestion, the pattern of digestion, and energy intake of the participant were varied ${ }^{18}$. In this context it may be too simplistic to administer a 'general' protein requirement. What is known however is that amino acids stimulate potent anabolic effects. Further, it appears that a relatively higher protein intake can positively effect indexes of performance, increase positive nitrogen balance, and enhance lean body mass. Wolfe summarizes by stating that:

"our results, along with virtually all data in the literature on the topic, suggest that increasing amino acid intake will increase muscle mass, with all other variables remaining constant. Whereas this concept runs counter to popular perception, real-life examples abound in obese individuals who have significantly elevated muscle mass despite living sedentary lives. Thus, it is likely that increasing amino acid intake...will promote muscle anabolism, whether in depleted individuals such as the elderly or in active athletes trying to increase muscle mass. The exact nutritional approach will determine the extent of anabolic response (emphasis added) ${ }^{18}$."

Summary of protein requirements. In summary protein requirements appear to be elevated for strength training athletes. This increased need is attributed to enhanced oxidation rates of endogenous amino acids during exercise ${ }^{27}$, the need for increased substrate to repair damaged muscle tissue ${ }^{12}$, and the capacity to maintain elevated protein synthesis for greater amounts of muscle tissue ${ }^{18}$. Techniques utilized to measure protein requirements include nitrogen balance methods ${ }^{15-17}$, tracer techniques ${ }^{13}$, and performance and body composition techniques ${ }^{28,29}$. Nitrogen Balance techniques suggest that the protein requirements to attain zero nitrogen balance range from 1.2-2.2 grams of protein per $\mathrm{kg}$ of bodyweight $1,7,14,23,24,31-33$. Further, there is evidence that nitrogen retention increases as nitrogen uptake increases ${ }^{16}$. Hegsted ${ }^{16}$ presented a series of studies which suggested that $20 \%$ of the nitrogen above maintenance is retained. However, these results have not directly translated to enhanced lean body mass 13,15-16. There are two rationales for these findings. The first is that nitrogen retention is inherently overestimated ${ }^{16}$, largely because nitrogen losses are underestimated ${ }^{16}$. A second rationale is that the overall length of most nitrogen balance studies do not allow for a statistically significant measure of LBM increases ${ }^{1}$.

Tracer techniques have been recently employed and generally support the protein requirements obtained through nitrogen balance studies ${ }^{13,24}$. In fact Tarnopolsky et al. ${ }^{13}$ found that protein synthesis increased from low $(0.8 \mathrm{~g} / \mathrm{kg})$ to moderate $(1.4 \mathrm{~g} / \mathrm{kg})$ intakes. While there was an $8.6 \%$ increase from moderate to high (2.4) protein intakes, these results did not reach significance. The authors suggested that this non significant trend appears to support the suggestion that the real protein requirements of athletes were closer to the 1.8 grams of protein per $\mathrm{kg}$ of bodyweight daily. Further, oxidation rates of leucine increased greatly from moderate to high protein intakes. This was taken as evidence that protein intakes above maintenance are oxidized. Unfortunately, these results are slightly confounded by the fact that the higher protein intake occurred through supplementation of whey protein, which enhanced the protein quality of the diet. This may cause an under estimation of the protein needs of athletes had they simply expanded their normal protein sources. Further, whey is a fast digesting 
protein and is known to naturally increase leucine oxidation rates ${ }^{5,6}$. Therefore, the increased oxidation rates may have been related to both an increase in protein intake, as well as a higher proportion of that intake coming from whey protein. Future studies will need to delineate between these variables.

Recently there have been a number of studies which have investigated higher protein intakes on indexes of performance and body composition ${ }^{28-30}$. A number of these studies have supported the efficacy of higher protein intakes, and yielded greater indexes of strength, and enhanced lean body mass ${ }^{28-30}$. This led Wolfe to conclude that increasing protein intake "will increase muscle mass, with all other variables remaining constant ${ }^{40}$.",

It is further known that a number of other variables affect protein intake. Perhaps the most critical of these is energy intake. When an individual is in a caloric deficit, protein needs are greater than when the individual is in maintenance or a caloric surplus ${ }^{34}$. Finally it has been recently postulated that a true general protein requirement may be impossible to find considering that studies strongly suggest that different results will be obtained with the same protein intake when a number of variables are manipulated ${ }^{1}$. The remainder of the paper will provide an in depth analysis of a number of these variables.

\section{DIGESTION RATE AS AN INDEPENDENT REGULATORY FACTOR OF NET PROTEIN BALANCE}

Net protein balance can be defined as the difference between protein synthesis and protein degradation ${ }^{44}$. Studies have examined both whole body protein synthesis (WBPS) ${ }^{25,44}$ as well as skeletal muscular protein synthesis (MPS) ${ }^{45}$. Substances can increase protein gain through stimulating a decrease in breakdown, or an increase in protein synthesis ${ }^{44}$. A great deal of interest over the last decade has focused on the digestion of proteins as an independent regulatory factor of WBPS and MPS $25,26,44$. The purpose of this section will be to analyze the most relevant data on protein digestion rate.

Whey and Casein protein. Typically casein and whey proteins are utilized to examine the effects of slow and fast digesting proteins on WBPB $25,26,44$. Whey protein is water soluble, mixes easily and is rapidly digested ${ }^{25}$. In contrast Casein is water insoluble, coagulates in the gut and is digested slower than whey protein ${ }^{25}$. Casein also has intrinsic properties such as opioid peptides which effect gastric motility ${ }^{47}$. Opioid peptides mimic some of the pharmacological properties of opiate drugs. When the opioid peptides found in casein bind to opiate receptors, they are thought to slow gastric motility ${ }^{47,48}$. This was supported by Daniel et al. ${ }^{47}$ who found that the differences in gastric emptying rate and gastric transit time between whey and casein proteins were abolished when an opiate-receptor antagonist was administered.

One of the inherent problems however with comparing whey protein to casein protein as a measure of the effect of digestion rate, is that the amino acid profiles of the proteins differ ${ }^{46}$. For example, whey protein has a higher leucine content then casein ${ }^{25}$. The branched chain amino acid (BCAA) leucine is thought to serve as a signal molecule for the quantity and quality of protein intake ${ }^{46}$. Evidence also supports leucine's role as a potent stimulator of protein synthesis ${ }^{46}$. Further, relative to other amino acids BCAAs are not generally degraded by splanchnic tissues, causing them to increase the availability of amino acids to stimulate muscular protein synthesis ${ }^{48}$. To correct for this discrepancy, studies typically control for leucine content by increasing the amount of casein administered ${ }^{25}$. However, an imbalance in nitrogen between conditions may confound the results that are obtained $^{26}$.

\section{STUDIES COMPARING SLOW AND FAST DIGESTING PROTEINS}

One particular study which has become a modern day classic was conducted by Boirie et al. ${ }^{25}$. These scientists investigated the effect of digestion rate on leucine kinetics. Leucine kinetics were inferred to reflect protein synthesis, breakdown, and oxidation, through leucine skeletal muscle uptake, release, and oxidation respectively. In the study, the authors utilized casein as a slow digesting protein and whey as a fast digesting protein. To control for leucine content, 43 grams of casein were administered compared to 30 grams of whey in 16 participants. The whey protein condition displayed a rapid increase in amino acid concentrations 100 minutes after administration. However, by 300 minutes, amino acid concentrations returned to baseline. In contrast, the casein condition displayed a slow increase in amino acid concentrations which remained elevated above baseline after 300 minutes. The whey protein raised protein synthesis by $68 \%$, compared to $31 \%$ in the casein condition. It is also important to note that oxidation of the ingested 
protein was higher in the whey protein condition than the casein condition. However, the casein condition produced a marked decrease in protein breakdown, where as whey protein did not significantly decrease protein breakdown. Overall casein produced a greater whole body leucine balance than the whey protein condition.

There were two main explanations offered for the differences in protein degradation. The first explanation concerns a difference in insulin concentrations. This did not appear to be the cause as no significant differences in plasma insulin concentrations were found between conditions. The second explanation was that the properties of amino acids which depress protein degradation may only be revealed in the presence of prolonged hyperaminoacidemia.

During the Boirie et al. ${ }^{25}$ investigation, while leucine was closely controlled, the nitrogen and amino acid profiles differed between conditions. In this context, Dangin et al. ${ }^{26}$ furthered this investigation by examining the effects of a fast digesting amino acid mixture to casein. In this study the fast digesting mixture had an extremely similar amino acid profile to the casein protein, and both were administered in 30 gram servings. The investigators furthered the experiment by administering 30 grams of whey protein in a single meal in comparison to 30 grams of whey protein administered in small servings every 20 minutes for a total of 240 minutes to mimic the slow digesting pattern of casein.

Amino acid concentrations for the fast digesting amino acid mixture and single whey protein meal rose rapidly at 20 minutes and lasted from 180-200 minutes. In contrast, the slow digesting meals (casein and multiple whey feedings) increased plasma amino acid concentrations at 20-40 minutes and maintained this elevation until 420 minutes. It was found that the fast digesting meals rapidly increased protein synthesis, did little to depress protein degradation, and increased protein oxidation rates above the slow digestion conditions. In contrast, the slow digesting meals slowly increased protein synthesis, markedly decreased protein degradation, and only moderately increased protein oxidation rates. Further the multiple whey protein meal condition reached a steady state of amino acid concentrations in a similar manner to the casein condition.

Overall, the casein produced greater protein balance than the amino acid mixture, while the multiple feedings of whey protein produced greater protein balance than the single whey protein feedings. Finally, the multiple whey protein feedings produced greater protein balance then the casein mixture. The later result may be due to the pattern of feeding, or to the quality of the protein. Because the pattern of plasma amino acid increases were similar, there is a high probability that the results seen are related to the quality of the protein intake. Because the leucine and nitrogen content was controlled for in this study, it further supports that digestion rate is an independent factor regulating protein kinetics. These results suggest that a slower digestion rate favors greater whole body protein balance, at least over a rapidly digesting protein. Further, the quality of the proteins ingested also appear to have an effect on net protein balance, with the whey protein conditions achieving greater protein balance than the casein conditions when digestion rate was controlled for.

The effect of added energy to fast and slow digesting proteins. While whey protein and casein have differential effects on protein kinetics, they are rarely consumed without an additional energy source. In this context Dangin and colleagues ${ }^{6}$ investigated the effect of whey and casein proteins combined with carbohydrates (54\% sucrose, $46 \%$ maltodextrins) and fats (91\% sunflower oil, $9 \%$ monoglycerides) on whole body protein kinetics in young and elderly participants. Conditions consisted of isoleucine and isonitrogenous conditions. In the isoleucine condition young and elderly participants were administered either 34 grams of casein or 22 grams of whey in an isoenergetic 850 calorie meal. In the isonitrogenous condition participants were administered 34 grams of whey.

The results indicated that the addition of energy slowed digestion and time to peak amino acids elevation in both meals. As with previous experiments the amino acids peaked and lowered to baseline at a more rapid rate in the whey conditions than the casein condition. However these differences were not as pronounced as when these proteins were administered alone in previous studies. It was found that protein balance was higher in these studies for all conditions then in previous studies when the proteins were administered alone. This was partially attributed to the protein sparing effect of the added energy. The additional results were fascinating. First, in the isoleucine condition the whey protein produced greater nitrogen balance in the elderly adults, while the casein produced greater nitrogen balance in the younger adults. However, when the whey protein was increased to 34 grams it produced greater nitrogen balance in both the young 
and elderly participants. The additional energy content had no effect on protein synthesis in any of the conditions. However it did decrease protein degradation greatly in the whey protein conditions, and slightly in the casein conditions.

There are a number of rationales for these findings. First, gastric emptying rate was slower in elderly than young individuals. This may explain the more pronounced effect of a greater protein balance with whey protein than casein in elderly than young individuals. The enhanced protein balance in the whey protein conditions was attributed to enhanced leucine content in the whey protein condition when the nitrogen intake was controlled for. The enhanced protein balance with the addition of energy was attributed to the hyperinsulemia experienced with carbohydrate intake and subsequent lowered protein degradation. This effect was not as pronounced in the casein condition, perhaps due to its already present depression of protein degradation irrespective of an added energy source. These results indicate that the enhanced protein balance of casein is reversed with the addition of energy.

The effect of exercise on protein kinetics when administered a slow and fast digesting protein. The effect of exercise on protein balance when administered a slow and fast digesting protein had not been investigated until recently. In this context, Tipton and colleagues ${ }^{49}$ administered 20 grams of whey or casein protein, exactly one hour after individuals exercised. The digestion rates of the proteins followed similar patterns to previous studies. However, rather then measure WBPS, the investigators examined skeletal muscular protein synthesis in the leg. No significant differences were found between conditions in muscular protein synthesis. This can be interpreted several ways. First, the authors measured muscular protein balance rather than WBPB. In WBPB studies casein stimulated greater WBPB than whey. However, when examining muscular protein synthesis it may differ. One rationale is that a WBPS did not accurately portray muscular protein synthesis due to splanchnic uptake of amino acids. According to Nair et al. ${ }^{50}$ muscular protein syntheses only accounts for $27 \%$ of total WBPS. This is due to splanchnic uptake and utilization of amino acids for protein synthesis. Post prandial uptake of amino acids into splanchnic tissues (liver and gastrointestinal tract) is divided into two primary protein pools consisting of the actual splanchnic tissues as well as the synthesis of proteins which are exported to the blood plasma (i.e. albumen) ${ }^{51}$. Research from De Feo and colleagues ${ }^{52}$ indicated that albumen synthesis alone accounted for $28 \%$ of WBPS. Of course these effects may change with resistance exercise. A second explanation is that this study utilized an isonitrogenous protocol, in that both conditions were administered 20 grams of protein. Perhaps the effect of additional nitrogen content in the whey condition differentially affected the results. However, this contention was not supported by the Dangdin et al. ${ }^{44}$ study. A third possibility is that exercise had a differential effect on protein kinetics. It is interesting that whey protein had similar effects on protein balance when compared to casein after exercise. If the addition of an energy source has similar effects on whey and casein as it did in the Dangin et al. ${ }^{6}$ study, then it could have strong implications for post exercise nutrition and enhanced protein balance. A further topic of study concerns the temporal nature of the protein delivery. Evidence suggests that the timing of protein intake can have strong effects on protein balance relative to exercise ${ }^{2-4}$ and that protein delivered immediately after exercise may have a more anabolic response than protein administered 1 hour after exercise ${ }^{2-4}$. If this is the case, then the differential effects of whey and casein administered immediately after exercise, as opposed to a delay would be of great scientific and practical interest.

Summary of the effect of digestion rate on whole body protein balance. Evidence from WBPS suggests that slow proteins produce a more favorable anabolic response than fast digesting proteins when administered without additional energy ${ }^{25,26}$. Slow digesting proteins moderately raise amino acid levels, but do so for a prolonged period of time ${ }^{25}$. Moderate and prolonged hyperaminoacidemia decreases protein breakdown, and moderately elevates protein synthesis ${ }^{25}$. In contrast fast digesting proteins stimulate a rapid rise and fall in protein synthesis, with little decrease in protein breakdown ${ }^{25}$. When protein synthesis and degradation are taken into account slow digesting proteins appear to be more anabolic when consumed in one meal, and the measurements are taken over extended periods of time ( i.e. 7 hours) ${ }^{25}$. How this fits within a daily meal schedule will be discussed in the pattern of digestion section of this paper.

In summary, casein appears to produce a greater protein balance than whey protein; however, when combined with a source of energy, whey protein produces greater protein balance than casein combined with a source of energy ${ }^{6}$. Because resistance trained athletes rarely consume protein alone, the latter findings may be more applicable. 


\section{OPTIMAL TIMING OF PROTEIN INGESTION RELATIVE TO EXERCISE}

In 2001 a perspectives paper was submitted by the eminent scientist Michael J. Rennie ${ }^{4}$. Amusingly enough the paper was entitled "Grandad, it ain't what you eat, it depends when you eat it - that's how muscles grow! ${ }^{4}$ " The paper was a brief review of a study published by Esmarck and colleagues ${ }^{2}$. Esmarck et al. ${ }^{2}$ investigated the effect of immediate and 2 hour delayed feedings of protein on muscular hypertrophy and strength over a 12 week period of resistance training in elderly males. An oral supplement of 10 grams of protein, 7 grams of carbohydrate, and 3 grams of fat was administered. Results indicated that both mean fiber area of the $\mathrm{m}$. vastus lateralis and cross sectional area of the $m$. quadriceps femoris increased in the immediate protein condition, where as no significant increases were found in the 2 hour delay condition. Both dynamic and isokinetic strength increased, by 46 and $15 \%$, respectively in the immediate condition, whereas the delayed condition only improved in dynamic strength, by $36 \%$.

These results indicate that immediate feeding after exercise is an important factor regulating muscle growth, at least in elderly individuals. There are a number of possible explanations for these results. The first is related to the observation that protein synthesis is stimulated in response to resistance training ${ }^{53}$. Phillips et al. ${ }^{53}$ found that these effects were inversely related to time (see Figure 2). Therefore, one possible explanation proposed by Esmarck et al. ${ }^{2}$ was that the substrate provided to participants and its interaction with the contractioninduced stimulation of protein synthesis was used to a lesser extent for the formation of muscle tissue in the delayed condition compared to the immediate condition.

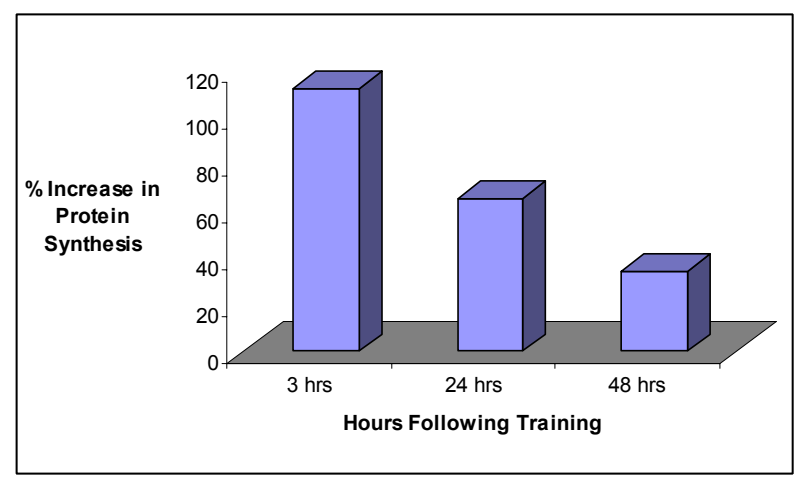

Figure 2. Percentage increase in Protein synthesis as a function of time following resistance training exercise. Data from Phillips et al. ${ }^{53}$

A further explanation concerns the relationship between blood flow and protein synthesis. Biolo et al. ${ }^{54}$ investigated the effect of infusing amino acids at rest and after exercise in healthy individuals. They found that while amino acid concentrations increased similarly in both conditions, that muscle blood flow was $64+/-5 \%$ greater after exercise than at rest. Further this corresponded with a $30-100 \%$ increase in amino acid transport compared to the resting condition. There was also a greater increase in skeletal muscle protein synthesis after exercise than at rest (291\% vs. $141 \%)$.

Biolo et al. ${ }^{54}$ suggested that exercise stimulates the opening of underpurfused capillaries and therefore, shortens the diffusion distance of amino acids and skeletal muscle cell membranes. Moreover a decrease in the proportion of blood delivered to splanchnic tissues may decrease the probability of uptake of amino acids by those tissues, and therefore allow a greater supply of substrate and signaling molecules immediately after exercise. Such an effect would diminish with time as blood is redistributed towards resting levels. Other possibilities concern insulin sensitivity which, appears to increase in response to exercise 55,56 . It may be that insulin sensitivity is higher immediately following exercise compared to two hours after exercise ${ }^{2}$.

These results suggest that it is critical to consume amino acids immediately following exercise. In contrast, Rasmussen et al. ${ }^{57}$ found no significant difference in phenylalanine balance when 6 grams of essential amino acids and 35 grams of sucrose were administered either 1 or 3 hours after the completion of a resistance training protocol. The discrepancy may be related to the age of the participants, as they were $34 \pm 3$ years of age compared to $74 \pm 1$ years of age in the Esmarck et al. ${ }^{2}$ investigation. However the differences may have also been related to the timing of the protein supplements. The differences in timing included an immediate and 2 hour feeding in the Esmarck et al. ${ }^{2}$ study, compared to a 1 and 3 hour delay in the Rasmussen et al. ${ }^{57}$ study. Another possibility is that the Esmarck et al. ${ }^{2}$ investigation measured more direct indexes of muscular hypertrophy over a 12 week period, as compared to a more acute protocol in the Rasmussent et al. ${ }^{57}$ investigation.

As an additional comparison, Levenhagen et al. ${ }^{3}$ administered an oral protein supplement (10 g 
protein, $8 \mathrm{~g}$ carbohydrate, $3 \mathrm{~g}$ fat) either immediately (EARLY) or three hours after moderate intensity exercise (LATE). Results indicated that Net balance was significantly more positive during EARLY, compared with LATE, for the amino acids measured. In fact, while there was a net uptake of amino acids with the EARLY condition, there was a net release of amino acids in the LATE condition. Further leg protein synthesis was more than 3 times greater in the EARLY condition than the LATE condition. Finally whole body protein deposition was greater in the EARLY condition than the LATE condition. What was interesting in these results was that plasma concentrations of glutamine were $19 \%$ greater when the supplement was given EARLY than LATE. Whether this result is related to the differences in protein synthesis or not is uncertain. However, glutamine has been shown to be the most prominent amino acid in the intracellular muscular amino acid pool ${ }^{58}$. Another interesting trend, which has been confirmed in a number of studies ${ }^{59}$ was that there was no significant difference in glucose uptake 3 hours after exercise than during rest. However, when administered immediately after exercise there was 3.5 times greater net glucose uptake than during rest or 3 hours after exercise. It is well known that for every gram of glycogen an additional 2.7 grams of water are stored in muscle tissue ${ }^{12}$. Additionally studies indicate that cellular hydration is a potent regulator of protein synthesis ${ }^{38,39}$, which may partly explain the differences in protein synthesis seen between immediate and late administrations of the supplements.

Ingestion of amino acids prior to exercise. While immediate consumption of amino acids combined with a carbohydrate source post exercise has been indicated to enhance protein accretion, it is important to understand the effect of a pre workout feeding on this parameter. In this context Tipton et al. ${ }^{60}$ had six participants consume a liquid meal of 6 grams of essential amino acids combined with 35 grams of sucrose (EAC solution) prior to exercise (PRE), or immediately after exercise (POST). Protein kinetics was measured at rest, during exercise and up to two hours post exercise. Results indicated that the PRE condition increased blood flow by $324 \%$ to the leg compared to a $201 \%$ increase in the post condition, and this corresponded with a $650 \%$ increase in phenylalanine delivery to the muscle compared to a $250 \%$ increase in the POST condition. Further, phenylalanine uptake across the leg was $160 \%$ greater in the PRE condition than the POST condition. Perhaps of most interest was the finding that protein balance went from negative at rest to positive during exercise and post exercise for the PRE condition, while the post condition remained negative during both rest and exercise, and turned positive after exercise. It is important to note that over the 3 hour measure that both the PRE and POST conditions were effective in turning the overall muscle balance from negative to positive. However this response was greater in the PRE than POST condition.

Before analyzing the mechanisms of these results it is important to recognize that the results favor the PRE condition, as each of the three hours following EAC consumption in the PRE trial were measured, where as the POST condition only measured two hours following EAC consumption. Therefore the authors made further calculations of only the final two hours of collection. However, even when measured this way there was an $80 \%$ greater amino acid uptake for the PRE than POST conditions. However, these results did not reach significance.

The timing element is critical in this study as blood flow is greatly increased by muscular contraction. This effect appeared to be heightened with ingestion of a pre workout amino acid solution. Further, the combined effects of increased blood flow and elevated amino acid concentrations elicited a potent anabolic stimulus. Typically net protein balance during exercise is negative, and while protein synthesis is stimulated following training, it either remains unchanged or is decreased during exercise ${ }^{60}$. However, protein degradation is markedly increased during exercise and results in a net negative protein balance ${ }^{60}$. As predicted by Tipton et al. ${ }^{60}$ the pre workout nutrition appeared to counter these effects.

Summarizing the data on protein timing relative to exercise. While protein synthesis is elevated up to 48 hours following an exercise session, protein degradation is also increased; resulting in a negative protein balance if additional nutrients are not supplied ${ }^{7}$. In this context, post workout amino acid feedings are critical to muscle protein accretion. Evidence from Rasmussen et al. ${ }^{57}$ suggests that there is no difference between amino acid consumption one and three hours after training. However long term results from Esmarck et al. ${ }^{2}$ and acute evidence from Levenhagen et al. ${ }^{3}$ suggests that immediate post exercise amino acid feedings provide a more favorable anabolic response than feedings 2-3 hours post exercise.

Pre-workout nutrition has also been indicated to be a 
critical component of stimulating muscular hypertrophy. Tipton et al. ${ }^{60}$ demonstrated that pre workout nutrition reversed the typically negative protein balance seen in exercise to a positive protein balance. Finally, evidence from Miller et al. ${ }^{61}$ indicated that amino acids delivered as short as one hour apart both stimulate similar anabolic responses. This suggests that a pre workout meal and post workout meal will have additive effects on protein synthesis.

\section{OPTIMAL PATTERN OF PROTEIN DIGESTION}

The following sections will discuss the pattern of protein digestion, which refers to how an individual consumes their protein throughout a 24 hour period, and what sources are utilized during this time zone.

Increase in Extra cellular EAA concentrations triggers Protein Synthesis. It appears that extra cellular concentrations of essential amino acids (EAA) serve as regulators of protein synthesis. In this context, Bohe et al. ${ }^{45}$ investigated the effect of increasing extra cellular EAA levels on muscular protein synthesis. Extra cellular concentrations of EAAs were increased from $41-235 \%$. It was found that protein synthesis increased in a curvilinear fashion in response to increasing levels of EAAs. However, no significant relationship was observed between intracellular amino acid availability of EAAs and protein synthesis. This explanation was suggested as the intra cellular concentration actually decreased slightly.

Therefore, it appears that an increase in extra cellular EAA concentrations serves as a trigger for protein synthesis rather than intramuscular concentrations. The rationale is that the extra cellular amino acid pool acts as an integrating center for several processes which increase or decrease amino acid availability ${ }^{45}$. These processes include an increase in amino acids through protein degradation from the liver and muscle tissue, as well as exogenous delivery of amino acids from diet. As an integration center, it is postulated that an extra cellular membrane bound sensor would be advantageous as it is in an optimal position to detect numerous bodily changes and to coordinate these changes to rates of protein synthesis 45. For example, a decrease in dietary amino acid delivery would not be conducive to utilizing limited resources for the production of new skeletal muscle tissue. In contrast, a rise in extra cellular amino acids would signal the opposite effect of enhancing protein accretion.
A decrease in extra cellular EAA concentration triggers decreases in protein synthesis despite absolute value. While studies have indicated a decrease in protein synthesis in response to a $50 \%$ decrease in blood EAA levels, and a subsequent return to basal protein synthesis after plasma EAA levels were returned to basal levels, it was not until recently when a delineation was made between amino acid availability being the trigger for protein synthesis, or the actual process of decreasing or increasing extra cellular amino acid concentrations serving as the trigger for protein synthesis. In this context Borsheim, Tipton., Wolf, and Wolfe. ${ }^{62}$ investigated the effects of 6 grams of EAAs and 6 grams of mixed EAAs and NEAAs (approximately 3 grams of each) on protein synthesis in two doses spaced 1 hour apart. They found a rise in plasma amino acid concentrations and an increase in protein synthesis after the first dose, with double the protein synthesis occurring in response to the 6 grams of EAAs as opposed to the mixed dosage. Further, while the amino acid concentrations remained elevated above basal levels one hour after administration, protein synthesis had returned to baseline. When the second dosage of EAAs was administered a similar anabolic response was seen in comparison to the first administration. These results led Wolfe ${ }^{40}$ to suggest that "it appears that an increasing concentration activates the synthetic process and the decline in concentration decreases synthesis, irrespective of the absolute value of the concentration."

Refractoriness in the system in response to intravenous infusion. One concept that has been adopted by bodybuilders is that of mimicking a constant and maintained supply of amino acids throughout the day. In a sense, they seek to mimic intravenous infusion. However, what would happen if an athlete could achieve this? Bohé et al. ${ }^{63}$ investigated this question by intravenously infusing amino acids into participants for 6 hours. Plasma amino acid concentrations were raised 1.7 fold and then maintained throughout the allotted period of time. Results found that protein synthesis rose from 30-60 minutes and remained elevated to a value of 2.8 fold for 1.5 hours. While plasma amino acid levels were maintained, protein synthesis returned to basal levels for the remaining four hours. These results suggest that the machinery responsible for protein synthesis becomes refractory to a prolonged elevation in plasma amino acids, at least when the concentration is maintained. The authors postulate that the inhibitory mechanism may be 
related to some type of protein stat mechanism. Perhaps what is most important are the implications from this study, which suggest that "amino acids are more efficiently utilized for maintaining lean body mass and providing substrate for wound healing when given in divided doses (as occurs with meal feeding) rather than with continuous application" ${ }^{63}$.

The addition of an in between meal amino acid supplement. Recently, Paddon-Jones et al. ${ }^{64}$ investigated if combining $30 \mathrm{~g}$ of carbohydrate and $15 \mathrm{~g}$ of essential amino acids (CAA) altered the metabolic response to a nutritionally mixed meal in healthy, recreationally active male volunteers. Results found that the supplement group experienced $25 \%$ greater nitrogen balance than the control group. Further the supplement did not blunt the anabolic response which occurred in a normal meal. These findings suggest that a fast digesting amino acid supplement between meals enhances anabolism throughout the day. These findings also support other studies which indicate that acute increases in protein synthesis are additive in nature to the normal protein synthesis which occurs in a given day ${ }^{40}$.

Integrating the data on the pattern of protein digestion. The above evidence suggests that an increase in extra cellular EAA concentrations stimulates an increase in protein synthesis, while a decrease in amino acid concentrations decreases protein synthesis. These results occur despite absolute concentrations of amino acids, meaning that a decrease in protein synthesis will occur even when amino acid concentrations remain elevated above basal levels. Protein synthesis in response to a rapid digesting source of amino acids has similar anabolic effects, even when administered only 1 hour apart. However, when amino acids are administered and maintained for a prolonged period of time, inhibitory mechanisms appear to act within a two hour time period. This led Bohe et al. ${ }^{63}$ to suggest that intermittent feedings may stimulate greater protein accretion than continual intravenous feedings.

Recently, Ha et al. ${ }^{65}$ suggested that the fast digesting response of whey protein may be beneficial as a source of amino acids which rapidly peaks and dissipates, so as to avoid the inhibitory mechanisms which occurred in the Bohe et al. ${ }^{63}$ study. In contrast they suggest that a casein source of protein between meals may have prolonged amino acid concentrations in a similar manner to intravenous infusion and therefore, cause a less than optimal anabolic response to in between meal amino acid feedings.
In summary, it appears that the pattern of protein feedings is optimized with intermittent feedings. If this is the case, an athlete should consume their normal meals, with intermittent amino acid feedings comprised of a fast digesting source of EAAs, such as a pure EAA supplement to maximize caloric efficiency, or a source of whey protein. A slow digesting source of protein between meals may hinder this anabolic response through a prolonged inhibitory mechanism, perhaps linked to some form of protein stat. Future research will need to investigate this suggestion.

\section{PROTEIN COMPOSITION AND QUALITY}

There are 20 total amino acids, comprised of 9 EAAs and 11 non essential amino acids (NEAAs). EAAs cannot be produced in the body and must therefore be provided exogenously through diet. Protein quality is typically defined as a protein's capacity to provide EAAs to an individual ${ }^{19,66}$. There are a number of methods utilized to determine protein quality, and there is much debate in their use ${ }^{66,67}$. In general these methods include the Chemical Score ${ }^{68,69}$, Protein Efficiency Ratio ${ }^{70}$, Biological value ${ }^{71}$, and the Protein Digestibility-Corrected Amino Acid Score (PDCAAS) ${ }^{66}$. While a review of each of these methods is beyond the scope of this paper, in general they are based on criteria pertaining to the composition of a protein, the absorbability of amino acids into bodily tissues, as well as the rate of growth in growing animals to any given source of protein (for a review on these methods see Brody ${ }^{9}$ ).

The effect of the composition / quality of a protein on lean tissue gains. Generally, animal based products contain the highest array of EAAs, while vegetable based products typically lack one or more EAAs ${ }^{12}$. In this context Campbell et al. ${ }^{72}$ investigated the effects of a lactoovovegetarian (meat free) diet compared to a omnivorous diet on body composition and muscular strength in male adults aged 51-69 years of age. The participants in the lactoovovegetarian diet condition were assisted by dieticians to ensure that they obtained adequate protein intake. Further, there was no significant difference between mean energy and macronutrient intakes between groups. Both conditions participated in a 12 week resistance training program. Results found a significant increase in fat free mass and a decrease in fat mass in the omnivorous condition. However, there was a decrease in fat free mass in the vegetarian condition and an increase in fat mass. These results indicate that a diet with the majority of 
its protein from meat products is more effective for supporting the goals of a resistance training program then a vegetarian diet.

In this context, it would be advisable for vegetarians to supplement their diets with an EAA supplement, preferably high in BCAAs such as leucine. Also of importance to vegetarians is the consumption of complementary proteins to enhance protein quality. Complimentary proteins are incomplete proteins (lacking or deficient in one or more EAAs) which when combined provide a complete array of essential amino acids ${ }^{12}$. The most common combinations come from grains and legumes (i.e. beans, lintels). Grains lack the EAA lysine, while legumes have lysine but lack the EAA methionine ${ }^{9}$ (see McArdle et al. ${ }^{12}$ for a review on complementary proteins).

In a study from McMaster University, Phillips et al. ${ }^{7}$ had participants consume 1 of three drinks immediately and one hour after exercise. The drinks consisted of $500 \mathrm{ml}$ of milk (18.2 grams of protein), an isonitrogenous and isoenergetic soy protein mixture, or a maltodextrin energy control condition.

After 12 weeks of resistance training it was found that the milk consumption condition gained significantly greater lean muscle mass than the energy control, while there were no significant differences between the energy control and soy protein conditions.

The effect of protein composition on peripheral and splanchnic tissue protein synthesis. Whole body protein synthesis is a function of both splanchnic ${ }^{72,73}$ and peripheral (i.e. muscular protein) synthesis ${ }^{74}$. Studies indicate that proteins which are deficient or have a low quantity of one or more EAAs preferentially increase splanchnic protein synthesis while decreasing peripheral skeletal muscular protein synthesis ${ }^{48,75}$. As an illustration Fouillet et al. ${ }^{48}$ had participants consume a mixture of sucrose and either 30 grams of milk or soy proteins. While soy is considered a complete protein, it contains $85 \%$ lower EAAs than milk. Further the EAA methionine is considered low in Soy ${ }^{76}$. The results indicated that the percentage of dietary nitrogen retention was higher in the milk protein condition than the soy protein condition. Further, the incorporation of dietary nitrogen into serum proteins was also higher in the soy protein condition than in the milk protein condition, indicating a greater use of amino acids for splanchnic tissue protein synthesis in the soy condition.

These results may be attributed to the faster digestion rate of soy, or to its low methionine content. The latter contention was supported by Lecavalier et al. ${ }^{75}$ who lowered the concentrations of one of two amino acids (either leucine or threonine) with hyperinsulemia, while maintaining the concentration of the other essential amino acids in blood plasma. Their findings indicated that peripheral protein synthesis was lowered while the synthesis of the two liver proteins measured was maintained. Further support comes from Martinez et al. ${ }^{77}$ who found that a legume based diet which is deficient in the EAA methionine caused severe atrophy of the gastrocnemius muscle compared to a casein based diet in rats. This was attributed to lowered muscular protein synthesis. However, liver protein synthesis was slightly increased in the legume-fed animals.

Finally, studies demonstrate that BCAAs are preferentially taken up by skeletal muscle tissue and poorly oxidized in splanchnic tissues ${ }^{78}$. In this context, a second factor to consider, is that Milk protein contains $120 \%$ more BCAAs than soy protein 48 .

The effect of protein composition on skeletal muscular protein synthesis. Amino acids have two critical attributes in the regulation of protein synthesis. First, they act as building blocks for the formation of new muscle tissue ${ }^{12}$, and secondly, they act as signaling molecules which stimulate the protein synthetic pathway ${ }^{62}$. In this context, a number of investigations have examined which amino acids are critical for the stimulation of protein synthesis. Numerous lines of research suggest that EAAs are the rate limiting nutrient that must be provided through diet for muscle tissue growth to occur ${ }^{79-81}$. In this context, Borsheim et al. ${ }^{62}$ investigated the effect of the ingestion of 6 grams of EAAs compared to 6 grams of mixed NEAAs and EAAs on protein synthesis post exercise. Comparison of protein synthesis among conditions found double the rate of protein synthesis in the EAA condition than the mixed amino acid condition. The authors concluded that the NEAAs were already provided in adequate amounts endogenously, and that EAAs act as signaling molecules independently of NEAAs. This finding was also supported by Volpi and colleagues ${ }^{83}$ who found that 18 grams of EAAs increased protein synthesis equally to a mixture of 18 grams of EAAs with additional ingestion of 22 NEAAs. Therefore, evidence strongly supports the contention of protein synthesis being directly related to the EAA content provided by a particular protein source.

Summary of protein quality. Protein quality is dependent on the availability of essential amino acids 
in a given protein source. Typically, protein quality is maximized in animal products, and increases when various protein sources are combined contiguously 9,12 .

\section{THE EFFECT OF CARBOHYDRATES AND FATS ON 24 HOUR NITROGEN BALANCE}

As has been discussed, energy has a tremendous nitrogen sparing effect ${ }^{34}$. However, a related topic concerns the differential effects of fats and carbohydrates on nitrogen balance. In this context, McCarger ${ }^{83}$ investigated the effects of a high carbohydrate or high fat diet on nitrogen retention, substrate utilization, and serum hormone concentrations in six healthy male participants. The diets were administered at maintenance and at $75 \%$ of maintenance calories. Results indicated that the high fat diet produced slightly greater nitrogen retention in the $75 \%$ restricted diet than the high carbohydrate diet, while no differences existed between diets at maintenance. Results such as this have led Millward to suggest that "for now energy intakes can be considered independently from the composition of that energy as determinants of NB, thus simplifying the issue ${ }^{34}$." However, these results need to be replicated; particularly, in the context of exercise training.

Carbohydrates and Fats in Resistance training exercise. While carbohydrates and fats may spare nitrogen in a similar manner, it is important to recognize that carbohydrates are critical for high intensity exercise. As an illustration Jacobs et al. ${ }^{84}$ investigated the effect of depleting muscle fibers of glycogen on strength levels. It was found that glycogen depletion in both fast and slow fiber types in the vastus lateralis was associated with impaired maximal muscular strength produced during a single dynamic contraction, as well as with increased muscle fatigue patterns. Further, it has been well established that a decrease in intensity can cause a significant loss of adaptation ${ }^{43,85-88}$. These results suggest that a decrease in carbohydrates may indirectly decrease muscle tissue, or impair further adaptations.

Interaction between carbohydrates and protein/ amino acid intake. Koopman and colleagues ${ }^{89}$ investigated the effects of carbohydrate $(0.3 \mathrm{~g}$ per kgper hour) (CHO), carbohydrate and protein $(0.2 \mathrm{~g}$ per kg-h) (CHO-PRO) and carbohydrates, protein and leucine ( $0.1 \mathrm{~g}$ per kg-h) (CHO-PROL) on net protein balance, and amino acid oxidation rates. Results indicated that net balance was negative in the $\mathrm{CHO}$ condition, and positive in the CHO-PRO and CHOPROL conditions, with the latter attaining the highest values. These results paralleled plasma insulin concentrations, with insulin being highest in the CHO-PROL condition, intermediate in the CHOPRO condition, and lowest in the $\mathrm{CHO}$ condition. The net balance was improved through increased protein synthesis and decreased protein breakdown in the CHO-PROL condition relative to the other two conditions. Further protein oxidation was lowest in the CHO-PROL condition. The rationale may be that leucine intake enhances insulin secretion ${ }^{89}$, and independently increases protein synthesis ${ }^{90,91}$. It is generally thought that insulin enhances protein balance through hindering protein degradation ${ }^{40,92}$, which was supported by this study.

However, the role of insulin in stimulating protein synthesis is in debate ${ }^{89}$. In vitro studies ${ }^{93-95}$ have supported insulin's role in regulating protein synthesis, while a number of in vivo studies have shown discrepancies in protein synthesis ${ }^{96}$. As an illustration Biolo et al. ${ }^{92}$ found that insulin infusion increased protein synthesis at rest, but not after resistance training exercise. The authors concluded that it was the decreased amino acid availability which depressed the stimulatory effect of insulin. This was supported by Biolo et al. ${ }^{97}$ when they found that maintained amino acid levels in the presence of hyperinsulemia increased protein synthesis. Further, Hiller and colleagues ${ }^{96}$ suggested that discrepancies seen between in vitro studies and in vivo studies centered around plasma concentrations of insulin. To test this question, Hiller et al. ${ }^{96}$ raised plasma insulin levels to concentrations similar to studies conducted in vitro, while maintaining amino acid concentrations. It was found that hyperinsulemia increased protein synthesis greatly. Therefore, mechanisms which enhance the insulin response to food may enhance protein accretion. The efficacy of combining carbohydrates and protein on insulin secretion was demonstrated by Ivy et al. ${ }^{98}$ who found that the combined effects of protein and a high glycemic carbohydrate were greater on stimulating insulin secretion than their independent effects.

Summary of the effect of carbohydrates and fats on protein balance. In summary it appears that both carbohydrates and proteins have similar nitrogen sparing effects 34,83 . In this context it may be advisable to increase fats when carbohydrates are lowered. However because carbohydrates are critical to athletic performance ${ }^{84}$ the athlete should be conscious of decreased intensity and performance with decreased carbohydrate intakes. Finally, there 
appears to be an interaction effect between protein and carbohydrates in stimulating insulin secretion ${ }^{98-}$ 100. This latter effect may be beneficial when manipulated for protein accretion purposes.

\section{PROTEIN SUPPLEMENTATION COMPARED TO A NORMAL MEAL}

Protein supplementation may provide a more anabolic response when compared to consumption of a normal meal. In the Paddon-Jones et al. ${ }^{64}$ study previously mentioned, participants were given an EAA supplement comprised of $30 \mathrm{~g}$ of carbohydrates and $15 \mathrm{~g}$ of EAAs. Interestingly enough, the study compared the anabolic response of the normal meal consumed to the EAA supplement. These scientists found that phenylalanine balance was much greater in the EAA supplement than the meal, even though both the meal and supplement contained 15 grams of EAAs. Further, the meal contained 850 calories compared to only 180 calories in the supplement. This led the authors to postulate that some intrinsic component of the meals decreased the anabolic response produced by the EAAs. The rationale proposed was that the slowed speed of the meal enhanced the efficiency of splanchnic uptake of amino acids relative to the supplement. In contrast, the rapid digestion of the EAAs may have decreased the efficiency with which the splanchnic tissues could extract amino acids, leaving a greater proportion of EAAs available to the peripheral muscle tissue.

These findings appear to contrast with studies which demonstrate a greater protein balance to a slow digesting protein as opposed to a fast digesting protein source ${ }^{25,26}$. At least two explanations arise for the discrepancy. First, Dangin et al. ${ }^{26}$ investigated the effect of digestion rates on WBPS, while Padon-Jones et al. ${ }^{64}$ investigated the effects of a meal and supplement on MPS. As has been discussed splanchnic tissues are largely responsible for whole body protein synthesis ${ }^{72,73}$. Secondly, this investigation included carbohydrates, which when combined with a fast digesting source of protein such as whey have been shown to produce a greater anabolic response even in studies which examine WBPS6.

Also of interest in this study is that the meal was comprised of a mainly casein based protein source, which contained 15 grams of EAAs with the remainder coming from NEAAs. This further supports the contention that extra cellular EAAs are responsible for protein synthesis irrespective of NEAA concentrations.
Finally a further outcome seen in this study was the benefit of increased caloric efficiency. A supplement can significantly increase protein accretion without a great excess of caloric intake, and therefore, avoid negative effects such as enhanced adipose tissue. Another apparent advantage of consuming supplements concerns the capacity for the supplement producer to control the degree of fractionation of a given protein. Fractionation can range from whole proteins, peptides, and lastly individual amino acids. When consumed whole, proteins are assimilated through a series of steps beginning with homogenization by chewing, followed by partial digestion by pepsin in the stomach ${ }^{9}$. Following, a combination of peptides, proteins, and negligible amino acids are released into the duodenum and either partially hydrolyzed into ogliopeptides, 2-8 amino acids in length, or fully hydrolyzed into individual amino acids 9,101 . Finally nitrogen can be absorbed into plasma as both small peptides (di, tri, and tetra peptides) and amino acids, through separate transport systems ${ }^{101}$.

In this context, a number of products contain proteins which have been pre exposed to specific digestive enzymes, causing hydrolysis of the proteins into di, tri, and tetra peptides. A plethora of studies have investigated the effects of the degree of protein fractionation on the absorption of amino acids and the subsequent hormonal response ${ }^{102}$. In terms of assimilation, research indicates that amino acids are absorbed more rapidly when consumed as di and tri peptides, than as either free form amino acids or whole proteins ${ }^{3,4}$.

Further, the rate of absorption may to lead to a more favorable anabolic hormonal environment ${ }^{2}$. As an illustration, Calbet et al. ${ }^{105}$ examined both amino acid appearance, and insulin responses after intakes of protein solutions containing the same amount of nitrogen, or pure carbohydrates. The solutions consisted of a pure glucose solution, pea (PPH) and whey peptide hydrolysates (WPH) and a cow's milk solution (MS) containing complete milk proteins. Each of the nitrogen containing solutions contained 15 grams of glucose. Results indicated that peptide hydrolysates produced a faster increase in venous plasma amino acids than did MS. Further, the peptide hydrolysates produced peak plasma insulin levels that were two and four times greater than that evoked by the MS and glucose solutions, respectively, with a correlation of ranging from 0.8 to 0.83 between plasma amino acids and the insulin response in the peptide hydrolysates. In summary, supplements appear to offer a number of advantages, including 
greater peripheral protein balance, caloric efficiency, and control over fractionation.

The effect of protein serving size on protein synthesis. A number of studies provide support that MPS is triggered by an increase in the concentration of EAAs ${ }^{62}$. For example Borsheim et al. ${ }^{62}$ found that 6 grams of EAAs produced double the protein synthesis as compared to only 3 grams of EAAs. Work from Bohe ${ }^{45}$ further explored this relationship and found it to be curvilinear in nature. This was illustrated when they enhanced extra cellular amino acid concentrations by $41-235 \%$. In this context, they found that protein synthesis was linearly related to increases in EAAs up to an $85 \%$ increase above basal levels, but that this response negatively accelerated for the remaining increases. It is important to analyze the details of their study. First, the authors infused amino acids at three different concentrations and included similar data from a fourth condition into individuals corresponding to $43.5,87,163$ or $261 \mathrm{mg}$ of mixed amino acids per $\mathrm{kg}$ per hour. This corresponded to 41, 82, 106, and 235 $\%$ increases in extra cellular EAAs, respectively. It was found that these increases in mean values corresponded to $30 \%, 57 \%, 72 \%$, and $88 \%$ increases in mixed muscle protein synthesis $(\mathrm{P}<0.05)$.

Therefore, while the response of protein synthesis lowered, it was still increasing in each condition in the experiment. The obvious problem when attempting to interpret the results of this study is that it is difficult to compare its' findings to oral feedings of amino acids. According to Tipton et al. ${ }^{81}$ the first pass of splanchnic uptake of amino acids accounts for a 20 to $90 \%$ uptake depending on the amino acid consumed, in turn seriously reducing the amount of amino acids reaching peripheral tissues. This means that a given intravenous dosage of amino acids may not be reflective of an oral dosage of the same magnitude in terms of the amount reaching peripheral tissues. However, Tipton et al. ${ }^{81}$ found that these differences were not as high as previously thought, and that several boluses of orally ingested amino acids may be as effective as infusion, making these results more generalizable. Regardless, this study does demonstrate a curvilinear increase in protein synthesis in response to an increase in extra cellular EAA concentrations. It also suggests that there is an upper limit to the amount of amino acids that can be consumed in a single setting to increase protein synthesis. This was supported by Tipton et al. ${ }^{81}$ who found that 40 grams of EAAs did not increase the effect of protein synthesis as compared to a 40 gram mixture of 20 grams of EAAs and 20 grams of NEAAs. These results suggest that the limitation was reached at or below 20 grams of EAAs. It should be noted however, that this study administered the protein over numerous small servings, which is not characteristic of normal feeding patterns.

Fortunately Dangin and colleagues ${ }^{6}$ compared 22 grams of whey, 33 grams of casein, and 33 grams of whey on WBPB. Each bolus was combined with carbohydrates and fats. The authors found that the 33 grams of whey protein promoted the greatest protein balance in both young and elderly individuals. However, it should be noted that this would vary with bodyweight. For example, the protein intake mentioned was an average of 33 grams in the high condition. But in reality the authors prescribed to each participant 0.48 grams of whey protein per $\mathrm{kg}$ of bodyweight. Therefore, a 200 pound man would have consumed roughly 43 grams of protein. The above results suggest that extra cellar EAAs increase protein synthesis in a curvilinear relationship to their concentration. While the upper limit is not known, studies suggest that an increase in protein intake from 22 to 33 grams of whey enhances protein balance. This level may increase with increasing body mass. Finally, there appears to be a limit at or below 20 grams of EAAs. Whether this latter result would change if delivered in a single bolus remains to be investigated.

\section{CONCLUSIONS}

The purpose of this review paper was to analyze past and contemporary issues in protein consumption for resistance trained athletes. The review analyzed the amount of protein needed daily by athletes, the optimal timing of protein intake relative to exercise, the optimal pattern of protein digestion, the role of protein quality in muscular hypertrophy, the effects of added energy on protein balance, as well as the efficacy of protein supplementation. A summary of practical applications can be found in Table 2, while a summary of future research implications can be found in Table 3. 
Table 2. Variables effecting protein accretion and indexes of performance for any given protein intake, and practical applications that follow from current evidence.

\begin{tabular}{|l|l|}
\hline \multicolumn{1}{|c|}{ Variable of Interest } & \multicolumn{1}{c|}{ Practical Applications } \\
\hline Pattern of Digestion & $\begin{array}{l}\text { Alternate normal meals with fast digesting sources of protein or } \\
\text { EAAs. }\end{array}$ \\
\hline Rate of Digestion & $\begin{array}{l}\text { Protein balance is greater with slow proteins with no additional } \\
\text { energy; however, when combined with a source of energy, whey } \\
\text { protein produces A greater protein balance than casein combined } \\
\text { with a source of energy. }\end{array}$ \\
\hline Timing of Protein Ingestion & $\begin{array}{l}\text { Consume EAAs or fast digesting protein prior to and } \\
\text { immediately following exercise. }\end{array}$ \\
\hline Protein Quality & $\begin{array}{l}\text { An omnivorous diet appears to be optimal for fat free mass and } \\
\text { indexes of performance, while supplementing with EAAs may } \\
\text { enhance protein accretion along with normal protein feedings. }\end{array}$ \\
\hline Amount per serving & $\begin{array}{l}\text { Unsure, but Dangin et al. }{ }^{6} \text { found an increase in protein synthesis } \\
\text { from 23 to 33 grams of whey protein. This may be near the limit } \\
\text { as 40 grams of EAAs did not increase MPS in comparison to 20 } \\
\text { grams of EAAs }{ }^{81}\end{array}$ \\
\hline Energy Source combined with Protein & $\begin{array}{l}\text { Both carbohydrates and fats appear to spare protein equally. } \\
\text { However, carbohydrates are still } \\
\text { critical for maintaining intensity during resistance training. }\end{array}$ \\
\hline
\end{tabular}

Table 3. Implications for Future Research

\begin{tabular}{|c|c|}
\hline Future Research Implications & Ways to Examine \\
\hline $\begin{array}{l}\text { 1. Finding more valid measures of protein balance and } \\
\text { degradation. }\end{array}$ & $\begin{array}{l}\text { Perhaps the most valid way would be to conduct more long } \\
\text { term chronic studies. }\end{array}$ \\
\hline $\begin{array}{l}\text { 2. The needs of athletes who train } 4-6 \text { hours daily with } \\
\text { resistance training. }\end{array}$ & $\begin{array}{l}\text { Possibly through nitrogen balance studies, and preferably } \\
\text { through chronic long term training. }\end{array}$ \\
\hline $\begin{array}{l}\text { 3. The protein requirements of athletes combining large } \\
\text { amounts of both resistance training and endurance } \\
\text { training exercise relative to either of these performed } \\
\text { alone. }\end{array}$ & $\begin{array}{l}\text { Possibly through nitrogen balance studies, and preferably } \\
\text { through chronic long term training. }\end{array}$ \\
\hline $\begin{array}{l}\text { 4. A study which attempts to analyze protein needs when } \\
\text { optimizing variables such as the timing of protein } \\
\text { ingestion, the pattern of protein ingestion, the rate } \\
\text { of digestion, the effect of added energy such as } \\
\text { carbohydrates to a protein containing meal, and the } \\
\text { quality of protein intake. }\end{array}$ & $\begin{array}{l}\text { Possibly through nitrogen balance studies, and preferably } \\
\text { through chronic long term training. }\end{array}$ \\
\hline $\begin{array}{l}\text { 5. Future examinations which attempt to analyze the } \\
\text { existence of a protein stat. }\end{array}$ & $\begin{array}{l}\text { Attempt to find some sort of antagonist to the suggested } \\
\text { membrane bound protein stat. This finding may allow } \\
\text { scientists a method of vastly enhancing protein synthesis in } \\
\text { both athletes, as well as populations with muscle } \\
\text { degenerative diseases. }\end{array}$ \\
\hline $\begin{array}{l}\text { 6. The timing of protein intake appears to enhance the } \\
\text { effects of any given protein bolus. Future research } \\
\text { should be done with other supplements in a similar } \\
\text { manner. }\end{array}$ & $\begin{array}{l}\text { Vary the timing of a number of supplements relative to } \\
\text { exercise training. }\end{array}$ \\
\hline $\begin{array}{l}\text { 7. More studies should be done on the nitrogen sparing } \\
\text { effects of carbohydrates verses fats particularly in the } \\
\text { context of exercise training. }\end{array}$ & Test sparing effects under exercising conditions. \\
\hline 8. What is the optimal serving of protein per serving & $\begin{array}{l}\text { A graded dosage study in small increments done on separate } \\
\text { days to analyze the acute effects as well as a cross sectional } \\
\text { study analyzing differing protein servings following exercise } \\
\text { on chronic gains. }\end{array}$ \\
\hline
\end{tabular}




\section{REFERENCES}

1. Tipton KD, Wolfe RR. Protein and amino acids for athletes. J Sports Sci. 2004, 22(1):65-79.

2. Esmarck, J. L. Andersen, S. Olsen, E. A. Richter, M. Mizuno, and M. Kjær. Timing of postexercise protein intake is important for muscle hypertrophy with resistance training in elderly humans. Physiol (Lond) 2001, 535: 301-311.

3. Levenhagen DK, Gresham JD, Carlson MG, Maron DJ, et al. Postexercise nutrient intake timing in humans is critical to recovery of leg glucose and protein homeostasis. Am J Physiol Endocrinol Metab. 2001, 280:E982-E993.

4. Rennie MJ. Grandad, it ain't what you eat, it depends when you eat it--that's how muscles grow! J Physiol. 2001, 535(Pt 1):2-2.

5. Layman DK, Baum JI. Influence of the protein digestion rate on protein turnover in young and elderly subjects. J Nutr. 2002, 132:3228S-33S.

6. Dangin M, Boirie Y, Guillet C, Beaufrere B. Influence of the protein digestion rate on protein turnover in young and elderly subjects. J Nutr. 2002, 132:3228S-33S.

7. Phillips SM, Hartman JW, Wilkinson SB. Dietary protein to support anabolism with resistance exercise in young men. J Am Coll Nutr. 2005, 24:134S-139S.

8. Rand, W. M., Pellett, P. L. \& Young, VR. Meta-analysis of nitrogen balance studies for estimating protein requirements in healthy adults. Am. J. Clin. Nutr. 2003, 77:109-127.

9. Brody T. Nutritional Biochemistry. 2nd ed. San Diego: Academic Press; 1999

10. Tomé D., Bos C. Dietary protein and nitrogen utilization. J. Nutr. 2000, 130:1868S-1873S

11. Alway SE, Grumbt WH, Stray-Gundersen J, Gonyea WJ. J Appl Physiol. 1992, 72:1512-21.

12. McArdle, W.D., Katch, F.I., \& Katch, V.L: Sports and exercise nutrition. Philadelphia, PA: Lippincott, Williams, \& Wilkins Publishing Co; 1999.

13. Tarnopolsky MA, Atkinson SA, MacDougall JD, Chesley A, Phillips S, Schwarcz HP. Evaluation of protein requirements for trained strength athletes. J Appl Physiol. 1992, 73:1986-95.

14. Lemon PW, Proctor DN. Protein intake and athletic performance. Sports Med. 1991, 12:313-25.

15. Tarnopolsky MA, MacDougall JD, Atkinson SA. Influence of protein intake and training status on nitrogen balance and lean body mass. J Appl Physiol. 1988, 64:187-93.

16. Hegsted DM. Assessment of nitrogen requirements. Am J Clin Nutr. 1978, 31:1669-77.

17. Waterlow JC. The mysteries of nitrogen balance. Nutr Res 1999, 12:25-54.

18. Wolfe, R.R. Protein supplements and exercise. Am J Clin Nutr. 2000, 72 (Suppl):551S-7S.

19. Tome D, Bos C. Dietary protein and nitrogen utilization. J Nutr. 2000, 130:1868S-73S.

20. Wolfe RR, Wolfe MH, Nadel ER, Shaw JH. Isotopic determination of amino acid-urea interactions in exercise in humans. J Appl Physiol. 1984; 56:221-9.

21. Carraro F, Hartl WH, Stuart CA, Layman DK, et al. Whole body and plasma protein synthesis in exercise and recovery in human subjects. Am J Physiol. 1990, 258(5 Pt 1):E821-31.

22. Carraro F, Kimbrough TD, Wolfe RR. Urea kinetics in humans at two levels of exercise intensity. J Appl Physiol. 1993, 75:1180-5.

23. Lemon PW. Beyond the zone: protein needs of active individuals. J Am Coll Nutr. 2000, 19(Suppl):513S-521S.

24. Lemon PW: Protein requirements of strength athletes. In Sports Supplements. Edited by Antonio, J., Stout, J. Philadelphia, PA: Lippincott, Williams, \& Wilkins Publishing Co.

25. Boirie, Y., Dangin, M., Gachon, P., Vasson, M. P., et al. Slow and fast dietary proteins differently modulate postprandial protein accretion. Proc. Natl. Acad. Sci. USA 1997, 94:14930-14935

26. Dangin, M., Boirie, Y., Garcia-Rodenas, C., Gachon, P., et al. The digestion rate of protein is an independent regulating factor of postprandial protein retention. Am. J. Physiol. 2001, 280:E340-E348.

27. Lemon PWR, Tarnopolsky MA, MacDougall JD, Atkinson SA: Protein requirements and muscle mass/strength changes during intensive training in novice bodybuilders. J Appl Physiol 1992, 73: 767-775,

28. Falvo, M. J., Hoffman, J. R.; Ratamess, N. A.; Kang, J. et al. Effect Of Protein Supplementation On Strength, Power And Body Composition Changes In Experienced Resistance Trained Men. Med Sci Sports Exercise 2005, Suppl 37: S45

29. Vukovich, MD.; Tausz, SM.; Ballard, TL.; Stevermer, CL.; et al. Effect of Protein Supplementation During a 6month Strength and Conditioning Program on Muscular Strength. Med Sci Sports Exercise 2004, Suppl 36::S193.

30. Burke DG, Chilibeck PD, Davidson KS, Candow DG, Farthing J, Smith-Palmer T. The effect of whey protein supplementation with and without creatine monohydrate combined with resistance training on lean tissue mass and muscle strength. Int J Sport Nutr Exerc Metab. 2001 11(3):349-64.

31. Batheja, and Stout Food: The Ultimate Drug. In Sports Supplements. Edited by Antonio, J., Stout, J. Philadelphia, PA: Lippincott, Williams, \& Wilkins Publishing Co.; 2001: 18-42.

32. Kreider, R. Effects of protein and amino acid supplementation on athletic performance. Sportscience 1999, 3: sportsci.org/jour/9901/rbk.html

33. Phillips SM. Protein requirements and supplementation in strength sports. Nutrition. 2004 Jul-Aug;20(7-8):689-95. Review. 
34. Millward DJ. Macronutrient intakes as determinants of dietary protein and amino acid adequacy. Nutr. 2004, 134(Suppl):1588S-1596S.

35. Munro, H. N. Carbohydrate and fat as factors in protein utilization and metabolism. Physiol. Rev. 1951, 31: 449-488.

36. Consolazio, C.F., H.L. Johnson, R.A., Nelson, J.G. Dramise, et al. Protein metabolism during intensive physical training in the young adult. Am. J. Clin. Nutr. 1975, 28: 29-35.

37. Ingwall JS. Creatine and the control of muscle-specific protein synthesis in cardiac and skeletal muscle. Circ Res. 1976, 38(Suppl 1):I115-23.

38. Millar, I.D. Mammary protein synthesis is acutely regulated by the cellular hydration state. Biochem. Biophys. Res. Commun. 1997, 230:351-355.

39. Waldegger, S. Effect of cellular hydration on protein metabolism. Miner. Electrolyte Metab. 1997, 23:201-205.

40. Wolfe RR. Regulation of muscle protein by amino acids. J Nutr. 2002, 132:3219S-24S.

41. Hakkinen, K., and M. Kallinen. Distribution of strength training volume into one or two daily sessions and neuromuscular adaptations in female athletes. Electromyogr. Clin. Neurophysiol. 1994, 34:117-124.

42. Wilson, JM, G.W. Wilson Specificity Part VI: The effect of Practice Distribution \& Contextual Interference on Performance \& Learning. Journal of Hyperplasia Research. 2005, 5: http://www.abcbodybuilding.com/taper2.php

43. Wilson, JM, G.W. Tapering Part 2 - Manipulation of Load for Peak Performance. Journal of Hyperplasia Research. 2005, 5: http://www.abcbodybuilding.com/taper2.php

44. Dangin, M., Y. Boirie, C. Garcia-Rodenas, P. Gachon, J. Fauquant, P. Callier, O. Ballevre, and B. Beaufrere. The digestion rate of protein is an independent regulating factor of postprandial protein retention. Am. J. Physiol. Endocrinol. Metab. 2001, 280:E340-E348.

45. Bohe J, Low A, Wolfe RR, and Rennie MJ. Human muscle protein synthesis is modulated by extracellular, not intramuscular amino acid availability: a dose-response study. J Physiol 2003, 552: 315-324.

46. Layman DK, and Baum JI. Dietary Protein Impact on Glycemic Control during Weight Loss. The American Society for Nutritional Sciences J. Nutr. 2004, 134:968S-973S

47. Daniel, H., Vohwinkel, M. \& Rehner, G. Effect of casein and B-casomorphins on gastrointestinal motility in rats. J. Nutr. 1990, 120:252-257.

48. Fouillet H, Mariotti F, Gaudichon C, Bos C, Tome D. Peripheral and splanchnic metabolism of dietary nitrogen are differently affected by the protein source in humans as assessed by compartmental modeling. J Nutr 2002, 132:12533

49. Tipton KD, Elliott TA, Cree MG, Wolf SE, Sanford AP, Wolfe RR. Ingestion of casein and whey proteins result in muscle anabolism after resistance exercise. Med Sci Sports Exerc. 2004, 36:2073-81.

50. Nair KS, Halliday D \& Griggs RC. Leucine incorporation into mixed skeletal muscle protein in humans. Am J Physiol 1988, 254, E208-213

51. Daenzer, M., Petzke, K. J., Bequette, B. J. \& Metges, C. C. Whole-body nitrogen and splanchnic amino acid metabolism differs in rats fed mixed diets containing casein or its corresponding amino acid mixture. J. Nutr. 2001, 131:1965-1972

52. De Feo P, Volpi E, Lucidi P, Cruciani G, Reboldi G, Siepi D, Mannarino E, Santeusanio F, Brunetti P, and Bolli GB. Physiological increments in plasma insulin concentrations have selective and different effects on synthesis of hepatic proteins in normal humans. Diabetes 42: 995-1002, 1993.

53. Phillips SM, Tipton KD, Aarsland A, Wolf SE, et al. Mixed muscle protein synthesis and breakdown after resistance exercise in humans. Am J Physiol. 1997, 273:E99-107.

54. Biolo G, Tipton KD, Klein S, Wolfe RR. An abundant supply of amino acids enhances the metabolic effect of exercise on muscle protein. Am J Physiol. 1997, 273:E122-9.

55. Dipietro L, Dziura J, Yeckel CW, Neufer PD. Exercise and improved insulin sensitivity in older women: evidence of the enduring benefits of higher intensity training. J Appl Physiol. 2006, 100:142-9.

56. Poehlman ET, Dvorak RV, DeNino WF, Brochu M, et al. Effects of resistance training and endurance training on insulin sensitivity in non-obese, young women: a controlled randomized trial. J Clin Endocrinol Metab 2000, 85: 2463-2468.

57. Rasmussen BB, Tipton KD, Miller SL, Wolf SE, Wolfe RR. An oral essential amino acid-carbohydrate supplement enhances muscle protein anabolism after resistance exercise. J Appl Physiol. 2000, 88(2):386-92.

58. Wilson, G.J. Glutamine-The Conditionally Essential Amino Acid. The Journal of Hyperplasia Research 2003, 4: http://www.abcbodybuilding.com/glutamine.php

59. Knowlden, A.P. A Scientific Investigation into the Rationality of Post Workout Carbohydrate Consumption. The Journal of Hyperplasia Research 2003, 4: http://www.abcbodybuilding.com/scientific.php

60. Tipton KD, Rasmussen BB, Miller SL, Wolf SE, Owens-Stovall SK, Petrini BE, and Wolfe RR. Timing of amino acid-carbohydrate ingestion alters anabolic response of muscle to resistance exercise. Am J Physiol Endocrinol Metab 2001, 281: E197-E206.

61. Miller SL, Tipton KD, Chinkes DL, Wolf SE, Wolfe RR: Independent and combined effects of amino acids and glucose after resistance exercise. Med Sci Sports Exerc 2003, 35:449-455. 
62. Borsheim E, Tipton KD, Wolf SE, Wolfe RR. Essential amino acids and muscle protein recovery from resistance exercise. Am J Physiol Endocrinol Metab. 2002, 283:E648-57.

63. Bohe J, Low JF, Wolfe RR, Rennie MJ. Latency and duration of stimulation of human muscle protein synthesis during continuous infusion of amino acids. J Physiol. 2001, 15;532:575-9.

64. Paddon-Jones D, Sheffield-Moore M, Aarsland A, Wolfe RR, Ferrando AA. Exogenous amino acids stimulate human muscle anabolism without interfering with the response to mixed meal ingestion. Am J Physiol Endocrinol Metab. 2005, 288(4):E761-7.

65. Ha E, Zemel MB. Functional properties of whey, whey components, and essential amino acids: mechanisms underlying health benefits for active people (review). J Nutr Biochem. 2003, 14:251-8.

66. Gertjan Schaafsma The Protein Digestibility-Corrected Amino Acid Score J. Nutr., 2000 130: 1865S-1867S.

67. Reeds P, Schaafsma G, Tome D, Young V. Criteria and significance of dietary protein sources in humans. Summary of the workshop with recommendations. J Nutr. 2000, 130:1874S-6S.

68. Block RJ, Mitchell HH. The correlation of the amino-acid composition of protein with their nutritive value. Nutr. Abstr. Rev. 1946; 16:249-278.

69. Munaver SM, Harper AE. Amino acid balance and imbalance. II. Dietary level of protein and lysine requirement. J Nutr. 1959 Sep;69:58-64.

70. Mitchell GV, Jenkins MY, Grundel E. Protein efficiency ratios and net protein ratios of selected protein foods. Plant Foods Hum Nutr. 1989;39:53-8.

71. Chiang AN, Huang PC. Excess energy and nitrogen balance at protein intakes above the requirement level in young men. Am J Clin Nutr. 1988, 48:1015-22.

72. Campbell WW, Barton ML Jr, Cyr-Campbell D, Davey SL, et al. Effects of an omnivorous diet compared with a lactoovovegetarian diet on resistance-training-induced changes in body composition and skeletal muscle in older men. Am J Clin Nutr. 1999, 70:1032-9.

72. De Feo, P., Horber, F. F. \& Haymond, M. W. Meal stimulation of albumin synthesis: a significant contributor to whole body protein synthesis in humans. Am. J. Physiol. 1992, 263:E794-E799

73. Stoll, B., Burrin, D. G., Henry, J., Yu, H., Jahoor, F. \& Reeds, P. J. Dietary amino acids are the preferential source of hepatic protein synthesis in piglets. J. Nutr. 1998, 128:1517-1524

74. Scornik, O. A., Howell, S. K. \& Botbol, E. Protein depletion and replenishment in mice: different roles of muscle and liver. Am. J. Physiol. 1997, 273:E1158-E1167.

75. Lecavalier L, De Feo P, Haymond MW. Isolated hypoisoleucinemia impairs whole body but not hepatic protein synthesis in humans. Am J Physiol. 1991, 261:E578-86.

76. Bos C, Metges CC, Gaudichon C, Petzke KJ, et al. Postprandial kinetics of dietary amino acids are the main determinant of their metabolism after soy or milk protein ingestion in humans. J Nutr. 2003, 133:1308-15.

77. Martinez, J. A., Goena, M., Santidrian, S. \& Larralde, J. Response of muscle, liver and whole-body protein turnover to two different sources of protein in growing rats. Ann. Nutr. Metab. 1987, 31:146-153

78. Biolo G, Tessari P. Splanchnic versus whole-body production of alpha-ketoisocaproate from leucine in the fed state. Metabolism. 1997, 46:164-7.

79. Millward, DJ, and Rivers JP. The nutritional role of indispensable amino acids and the metabolic basis for their requirements. Eur J Clin Nutr 1988, 42: 367-393

80. Wolfe RR , \& Miller SL. Amino acid availability controls muscle protein metabolism. Diabetes Nutr Metab 1999, 12, $322-328$

81. Tipton, KD, Gurkin BE, Matin S, and Wolfe RR. Nonessential amino acids are not necessary to stimulate net muscle protein synthesis in healthy volunteers. J Nutr Biochem 1999, 10: 89-95.

82. Volpi E, Sheffield-Moore M, Rasmussen BB, and Wolfe RR. Basal muscle amino acid kinetics and protein synthesis in healthy young and older men. JAMA 2001, 286: 1206-1212.

83. McCargar, L. J., Clandinin, M. T., Belcastro, A. N. \& Walker, K. Dietary carbohydrate-to-fat ratio: influence on whole-body nitrogen retention, substrate utilization, and hormone response in healthy male subjects. Am. J. Clin. Nutr. 1989, 49: 1169-1178.

84. Jacobs, I., P. Kaiser, and P. Tesch. Muscle strength and fatigue after selective glycogen depletion in human skeletal muscle fibers. Eur. J. Appl. Physiol. 1981, 46:47-53.

85. Hickson RC, Rosenkoetter MA.. Reduced training frequencies and maintenance of increased aerobic power. Med. Sci. Sports Exerc. 1981, 13:13-16.

86. Hickson RC, Kanakis C Jr, Davis JR, Moore AM, Rich S. Reduced training duration effects on aerobic power, endurance, and cardiac growth. J. Appl. Physiol. 1982, 53:225-229.

87. Hickson RC, Foster C, Pollock ML, Galassi TM, Rich S. Reduced training intensities and loss of aerobic power. J Appl Physiol. 1985, 58:492-9.

88. Shepley B, MacDougall JD, Cipriano N, Sutton JR, Tarnopolsky MA, Coates G. Physiological effects of tapering in highly trained athletes. J Appl Physiol. 1992, 72:706-11. 
89. Koopman R, Wagenmakers AJ, Manders RJ, Zorenc AH et al. Combined ingestion of protein and free leucine with carbohydrate increases postexercise muscle protein synthesis in vivo in male subjects. Am J Physiol Endocrinol Metab. 2005, 288:E645-53.

90. Crozier, j. Scot R. Kimball, Sans W. Emmert, Joshua C. Anthony, and Leonard S. JeffersonOral Leucine Administration Stimulates Protein Synthesis in Rat Skeletal Muscle J. Nutr., 2005 135: 376-382.

91. Garlick J. The Role of Leucine in the Regulation of Protein Metabolism J. Nutr. 2005, 135: 1553S-1556S.

92. Biolo, G., Williams, B. D., Fleming, R. Y. \& Wolfe, R. R. Insulin action on muscle protein kinetics and amino acid transport during recovery after resistance exercise. Diabetes 1999, 48:949-957

93. Airhart J, Arnold JA, Stirewalt WS, Low RB. Insulin stimulation of protein synthesis in cultured skeletal and cardiac muscle cells. Am J Physiol. 1982, 243(1):C81-C86.

94. Manchester KL, Young FG. The effect of insulin on incorporation of amino acids into protein of normal rat diaphragm in vitro. Biochem J. 1958, 70:353-358.

95. Jefferson LS, Koehler JO, Morgan HE. Effect of Insulin on Protein Synthesis in Skeletal Muscle of an Isolated Perfused Preparation of Rat Hemicorpus. Proc Natl Acad Sci U S A., 1972 69:816-820.

96. Hillier, T. A., Fryburg, D. A., Jahn, L. A. \& Barrett, E. J.Extreme hyperinsulinemia unmasks insulin effect to stimulate protein synthesis in the human forearm. Am. J. Physiol. 1998, 274:E1067-E1074

97. Biolo, G., Fleming, R. Y. \& Wolfe, R. R. Physiologic hyperinsulinemia stimulates protein synthesis and enhances transport of selected amino acids in human skeletal muscle. J. Clin. Invest. 1995, 95:811-819.

98. Ivy JL, Goforth HW Jr, Damon BM, McCauley TR, et al. Early postexercise muscle glycogen recovery is enhanced with a carbohydrate-protein supplement. J Appl Physiol. 2002, 93:1337-44.

99. Zawadzki KM, Yaspelkis BB 3rd, Ivy JL. Carbohydrate-protein complex increases the rate of muscle glycogen storage after exercise. J Appl Physiol. 1992, 72:1854-9.

100. Tarnopolsky MA, Bosman M, Macdonald JR, Vandeputte D, Martin J, Roy BD. Postexercise protein-carbohydrate and carbohydrate supplements increase muscle glycogen in men and women. J Appl Physiol. 1997, 83:1877-83.

101. Silk DB, Grimble GK, Rees RG. Protein digestion and amino acid and peptide absorption. Proc Nutr Soc. 1985, 44:63-72.

102. Manninen, A.H. Protein hydrolysates in sports and exercise: a brief review. J Sports Sci \& Med. 2004, 3: 60-63

103. Collin-Vidal C, Cayol M, Obled C, Ziegler F, Bommelaer G, Beaufrere B. Leucine kinetics are different during feeding with whole protein or oligopeptides. Am J Physiol. 1994, 267(6 Pt 1):E907-14.

104. Craft IL, Geddes D, Hyde CW, Wise IJ, Matthews DM. Absorption and malabsorption of glycine and glycine peptides in man. Gut. 1968, 9:425-37.

105. Calbet JA, MacLean DA. Plasma glucagon and insulin responses depend on the rate of appearance of amino acids after ingestion of different protein solutions in humans. J Nutr. 2002, 132:2174-82. 